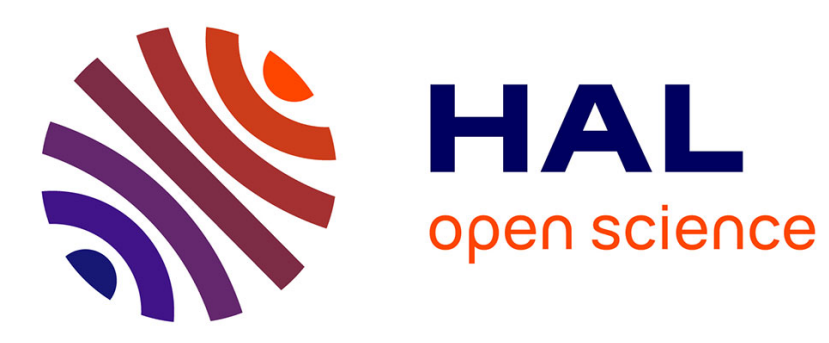

\title{
Synthesis, molecular structure, photophysical properties and spectroscopic characterization of new 1D-magnesium(II) porphyrin-based coordination polymer
}

\author{
N. Amiri, M. Hajji, Thierry Roisnel, G. Simonneaux, H. Nasri
}

\section{To cite this version:}

N. Amiri, M. Hajji, Thierry Roisnel, G. Simonneaux, H. Nasri. Synthesis, molecular structure, photophysical properties and spectroscopic characterization of new 1D-magnesium(II) porphyrin-based coordination polymer. Research on Chemical Intermediates, 2018, 44 (9), pp.5583-5595. 10.1007/s11164018-3442-9 . hal-01874731

HAL Id: hal-01874731

https://hal-univ-rennes1.archives-ouvertes.fr/hal-01874731

Submitted on 18 Sep 2018

HAL is a multi-disciplinary open access archive for the deposit and dissemination of scientific research documents, whether they are published or not. The documents may come from teaching and research institutions in France or abroad, or from public or private research centers.
L'archive ouverte pluridisciplinaire HAL, est destinée au dépôt et à la diffusion de documents scientifiques de niveau recherche, publiés ou non, émanant des établissements d'enseignement et de recherche français ou étrangers, des laboratoires publics ou privés. 
Synthesis, Molecular structure, Photophysical Properties and Spectroscopic Characterization of New 1D-Magnesium (II) Porphyrin-Based

Coordination Polymer

\author{
N. Amiri ${ }^{\text {a }}$ M. Hajji ${ }^{\text {b, }}{ }^{*} \cdot$ T. Roisnel $^{c} \cdot$ G. Simonneaux $^{c} \bullet$ H. Nasri ${ }^{\text {a }}$ \\ ${ }^{\text {a }}$ Laboratory of Physical Chemistry of Materials, University of Monastir, Avenue of the \\ Environment, 5019 Monastir, Tunisia. \\ ${ }^{\mathrm{b}}$ Research Unit: Electrochemistry, Materials and Environment, University of Kairouan, 3100 \\ Kairouan, Tunisia. \\ c Institute of Chemical Sciences of Rennes UMR 6226, University of Rennes 1, Beaulieu \\ Campus, 35042 Rennes, France. \\ * Corresponding author: E-mail: melekhajji1989@gmail.com \\ T: (+216) 55367281 ORCID: 0000-0002-6145-2858.
}


Abstract Chemical preparation, X-ray diffraction, spectral and photophysical studies were performed for $\mathrm{H}_{2}$ TPBP (5,10,15,20-tetrakis[4 (benzoyloxy)phenyl] porphyrin), [Mg(TPBP)], and the $\left[\mathrm{Mg}^{\mathrm{II}}(\mathrm{TPBP})(4,4 \text { '-bpy })_{2}\right]$ (I) complex (4,4'-bpy = 4,4'-bipyridine). This study shows a $1 \mathrm{D}$ coordination polymer chain of alternating $\left[\mathrm{Mg}^{\mathrm{II}}(\mathrm{TPBP})\right]$ and $4,4^{\prime}$-bipyridine molecule located at the axial position of the magnesium(II) coordination sphere. The magnesium ion is coordinated to four nitrogen atoms from the porphyrin ring and two nitrogen atoms from the axial ligands, forming a regular octahedron. The crystal packing and the linear coordination chains for this complex are stabilized by weak inter and intramolecular interactions involving centroids (Cg) porphyrin pyrrole and the pyridyl group of the 4,4'-bipyridine rings. Infrared (IR), proton nuclear magnetic resonance ( ${ }^{1} \mathrm{H}$ NMR) spectroscopies, mass spectroscopy, and elemental analysis were also investigated to confirm the crystal structure. UV-Visible absorption spectrum of complex I displayed a red shifted Soret (430 nm) and Q (571 and 614 $\mathrm{nm}$ ) bands due to the extended conjugation. However, fluorescence emission spectrum shows larger blue shift of $\sim 41$ and $\sim 54 \mathrm{~nm}$ for $Q(0,0)$ and $Q(0.1)$, respectively.

Keywords Crystal structure $\bullet \mathrm{Mg}(\mathrm{II})$-porphyrin coordination polymer $\bullet$ FT-IR and NMR spectroscopies $\bullet U$ U-visible $\bullet$ Fluorescence

\section{Introduction}

Synthesis and functionalization of porphyrins and associating metal complexes have long been of great interest in the chemistry community because of their remarkable applications such as catalysis [1-3], solar cells [4], chemical sensors [5], building blocks of assemblies [6] and so forth. Porphyrins were reported to exhibit a variety of biological activities [7-11], notably several derivatives based on this molecule had been developed as excellent photosensitive agents of photodynamic therapy (PDT) in clinical applications [1214]. During the past decade, numerous porphyrinic coordination polymers have been designed by using different methods [15-19], especially based on the axial coordination to the metal of a metalloporphyrin through the nitrogen atoms of a bidentate ligand [20]. The ditopic ligands (i.e., a ligand with two coordination sites) such as 4,4'-bipyridine, pyrazine, DABCO, and 4,4'-dipyridylamine have been extensively used to construct different coordination polymers [21-25]. Goldberg and co-workers [26], reported a 1Dcoordination polymers $\left(\left[\mathrm{Mn}^{\mathrm{III}}(\mathrm{TIPP})(\mathrm{L})\right]_{\mathrm{n}}\right)$ with other type of ligands: isonicotinate or pyrimidine-5-carboxylate. Based on 3,4,5-trimethoxyphenylporphyrin, two complexes have been synthesised, MgTMPP and ZnTMPP [27]. These structures consist of a onedimensional (1D) networks connected by the bond between metals ( $\mathrm{Mg}$ or $\mathrm{Zn}$ ) and oxygen atoms of the m-methoxy groups. The specific geometry of these materials determines their physicochemical properties, especially their photophysical behaviour in energy or electron transfer processes [29,30]. Recently, our research group has been working on the design and characterization of new metalloporphyrin-based materials, in which 4,4'-bipyridine ligand was used $\left\{\left[\mathrm{Co}^{\mathrm{II}}(\mathrm{porph})\left(4,4^{\prime} \text {-bpy }\right)_{2}\right]\right\}_{\mathrm{n}}$ (porph $=$ TpivPP or TPP) [21]. In the present study we have synthesised a new meso-substituted porphyrin $\left[\mathrm{Mg}^{\mathrm{II}}(\mathrm{TPBP})\right]$ by combining an ester function comprising two benzene rings with magnesium(II) atom. Development of ester functions with porphyrins have attracted much attention thanks to their wide range of applications [30-32]. The porphyrin 
framework was then combined with 4,4'-bipyridine to design a novel 1D coordination polymer bis(4,4'-bpy)(5,10,15,20-tetrakis[4-(benzoyloxy)phenyl] porphyrinato) magnesium(II) (I). Prepared compound was characterized by single crystal X-Ray diffraction, FT-IR, ${ }^{1} \mathrm{H}-\mathrm{NMR}$, UV-Visble, and fluorescence spectroscopies.

\section{Materials and methods}

\section{Syntheses and Crystallization}

Synthesis of meso-tetrakis[4-(benzoyloxy)phenyl]porphyrin $\left(\mathrm{H}_{2} \mathrm{TPBP}\right)$ and meso-tetrakis[4-(benzoyloxy)phenyl]porphyrinato)mangesium(II) complex [Mg $\left.{ }^{\mathrm{II}}(\mathrm{TPBP})\right]$ were made according to methods described in the literature $[33,34]$. Scheme S1 gives the main steps of the preparation method.

Synthesis of the meso-tetrakis[4-(benzoyloxy) phenyl] porphyrin ( $\left.\mathrm{H}_{2} \mathrm{TPBP}\right)$ : 4formylphenylbenzoate (500 mg, $2.21 \mathrm{mmol})$, and pyrrole $(153 \mu \mathrm{L}, 2.21 \mathrm{mmol})$ were added to distilled chloroform (300 mL) in a double necked round bottom flask under argon and shielded from light. Boron trifluoride diethyl etherate, $\mathrm{BF}_{3}$. $\mathrm{OEt}_{2}(192.4 \mu \mathrm{L}, 0.73 \mathrm{mmol})$ was added. The reaction was kept at room temperature for two hours. Two pipettes of triethylamine and 0.75 equivalents of p-chloranil (179.2 mg, $1.66 \mathrm{mmol}$ ) were added and the solution was heated to reflux (light protection was removed). After 1 hour, obtained solution was cooled to room temperature. Solvent was evaporated and the residue was filtered over silica with $\mathrm{CHCl}_{3} /$ hexane/ (1:9). Expected compound was obtained as a purple solid (yield 57\%). Spectroscopic analysis: ${ }^{1} \mathrm{H}$ NMR [300 MHz, $\left.\mathrm{CDCl}_{3}\right] \delta$ (ppm) 8.91 (s, 8H, H $\beta$-pyrrol), 8.42 (d, 8H, J=7.5 Hz), 8.33 (d, 8H, J=7.6 Hz), 7.71 (d, 8H, J=7.5 Hz), 7.59 (m, 12H), -2.80 (s, 2H, Hpyrrol). UV/vis [ $\lambda_{\max }(\mathrm{nm})$ in $\mathrm{CH}_{2} \mathrm{Cl}_{2}$, (log $\varepsilon$ )]: 419 (5.90), 514 (4.46), 551 (4.13), 590 (3.94), 646 (3.84). MS [ESI]: $\mathrm{m} / \mathrm{z}$ calcd for $\mathrm{C}_{72} \mathrm{H}_{46} \mathrm{~N}_{4} \mathrm{O}_{8}: 1095.16$ found: 1095.17. Anal. Calcd. For $\mathrm{C}_{72} \mathrm{H}_{46} \mathrm{~N}_{4} \mathrm{O}_{8}$ : C 78.96 H 4.23, N 5.12 \%; found: C 78.72, H 4.22, N 5.20 \%. FTRIR $\mathrm{cm}^{-1}: 3329$ ( $v_{\mathrm{NH}}$ porphyrin), 2964-2861 ( $v_{\mathrm{CH}}$ porphyrin), 1735 ( $v_{\mathrm{C}=\mathrm{O}}$ ester), 1267 ( $v_{\mathrm{C}-\mathrm{O}}$ ester), 987 ( $\delta_{\mathrm{CCH}}$ porphyrin).

Synthesis of the (meso-tetrakis[4 (benzoyloxy)phenyl] porphyrinato)magnesuim(II) complex [Mg(TPBP)]: $\mathrm{H}_{2}$ TPBP (0.6 g, $\left.0.54 \mathrm{mmol}\right)$ was dissolved in DMF $(150 \mathrm{~mL})$. The solution was heated under reflux with magnetic stirring. Upon dissolution of the $\mathrm{H}_{2} \mathrm{TPBP}, \mathrm{MgCl}_{2}$ ( $1 \mathrm{~g}, 10.8$ mmol) was added. The reaction mixture was stirred for 6 hours. thin-layer chromatography (alumina, using $\mathrm{CH}_{2} \mathrm{Cl}_{2}$ as eluant) indicated no free base porphyrins at this point. After that, the solution was cooled to $50-60{ }^{\circ} \mathrm{C}$ and $\mathrm{H}_{2} \mathrm{O}(50 \mathrm{~mL})$ was added into it. Obtained solid was filtrated and washed with hexane. The resulting was vacuum-dried to afford $66 \%$ yield of MgTPBP. Spectroscopic analysis: ${ }^{1} \mathrm{H}$ NMR $\left(300 \mathrm{MHz}, \mathrm{CDCl}_{3}\right) \delta(\mathrm{ppm}) 8.96(\mathrm{~s}, 8 \mathrm{H}, \mathrm{H} \beta-$ pyrrol), 8.67 (d, 8H, $J=6.4 \mathrm{~Hz}$ ), 8.36 (d, 8H, $J=8.33 \mathrm{~Hz}), 7.78$ (d, 8H, $J=8.8 \mathrm{~Hz}), 7.59$ (m, 12H). UV/vis $\left[\lambda_{\max }(\mathrm{nm})\right.$ in $\mathrm{CH}_{2} \mathrm{Cl}_{2}$, $(\log \varepsilon)$ ]: 427 (5.86), 565 (4.42), 605 (4.16). MS [ESI]: $\mathrm{m} / \mathrm{z}$ calcd for $\mathrm{C}_{72} \mathrm{H}_{44} \mathrm{MgN}_{4} \mathrm{O}_{8}$ : 1117, 3082, found: 1117, 3848. Anal. Calcd. For $\mathrm{C}_{72} \mathrm{H}_{44} \mathrm{~N}_{4} \mathrm{O}_{8}$ : C 77.39 H 3.97, N $5.01 \%$; found: C 75.22, H 3.22, N $5.20 \%$. FTR-IR cm ${ }^{-1}$ : 2965-1860 ( $v_{\mathrm{CH}}$ porphyrin), 1735 ( $v_{\mathrm{C}=\mathrm{O}}$ ester), 1267 ( $v_{\mathrm{C}-\mathrm{O}}$ ester), 993 ( $\delta_{\mathrm{CCH}}$ porphyrin). 
Synthesis and crystallization of $\left[\mathrm{Mg}^{\mathrm{II}}(\mathrm{TPBP})\left(4,4^{\prime}-b p y\right)_{2}\right]$ (I): [Mg $\left.{ }^{\mathrm{II}}(\mathrm{TPBP})\right]$ (20 mg, 0.017 mmol) and 4,4'-bipyridine (90 $\mathrm{mg}, 0.57 \mathrm{mmol}$ ) in $5 \mathrm{~mL}$ of dichloromethane (DCM) were stirred overnight at room temperature and the color of the reaction mixture changed from purple to blue-purple. Crystals of the desired complex were obtained by slow diffusion of nhexane through the dichloromethane solution.

Spectroscopic analysis: ${ }^{1} \mathrm{H}$ NMR $\left[\mathrm{CDCl}_{3}, 300 \mathrm{MHz}\right]: \delta_{\mathrm{H}}$ (ppm.) 8.98 (s, 8H, H $\beta$-pyrrol), 8.46 (d, 8H, J=6.4 Hz), 8.37 (d, 8H, $J=8.80 \mathrm{~Hz}$ ), 7.77 (d, 8H, J=8.6 Hz), 7.67 (m, 12H), 6.64 (d, $4 \mathrm{H}$-ligand, $\mathrm{J}=6.4 \mathrm{~Hz}$ ). UV/vis $\left[\lambda_{\max }(\mathrm{nm})\right.$ in $\mathrm{CH}_{2} \mathrm{Cl}_{2}$, (log $\left.\left.\varepsilon\right)\right]: 430$ (6.04), 571 (5.08), 614 (5.00). MS [ESI]: $\mathrm{m} / \mathrm{z}$ calcd for $\mathrm{C}_{82} \mathrm{H}_{52} \mathrm{MgN}_{6} \mathrm{O}_{8}: 1274.6306$ [M+H] $]^{+}$, found: 1274.3146. Anal. Calcd. for $\mathrm{C}_{82} \mathrm{H}_{52} \mathrm{MgN}_{6} \mathrm{O}_{8}$ : C; 77.32; H; 4.11; N; 6.59. Found: C; 77.15; H; 4.13; N; 6.59. FTR-IR cm ${ }^{-1}$ : 2928-2855 ( $v_{\mathrm{CH}}$ porphyrin), 1735 ( $v_{\mathrm{C}=\mathrm{O}}$ ester), 1609 ( $v_{\mathrm{C}-\mathrm{N}} 4,4^{\prime}$-bpy), 1602 ( $v_{\mathrm{C}-\mathrm{C}} 4,4^{\prime}$-bpy), $1463\left(\delta_{\mathrm{C}-\mathrm{H}}, \delta_{\mathrm{C}-\mathrm{N}} 4,4^{\prime}\right.$-bpy), 1267 ( $v_{\mathrm{C}-\mathrm{O}}$ ester $), 1000$ ( $\delta_{\mathrm{CCH}}$ porphyrin), 846 $\left(\gamma_{\mathrm{C}-\mathrm{H}} 4,4^{\prime}-\mathrm{bpy}\right)$.

\section{X-ray diffraction analysis}

Blue-purple crystal with approximate dimensions of $0.12 \mathrm{~mm} \times 0.25 \mathrm{~mm} \times 0.08 \mathrm{~mm}$ was selected for the X-ray diffraction experiment. Data collection was performed on a Bruker APEX-II diffractometer. Diffractometer was equipped with graphite monochromated Mo K $\alpha$ radiation $(\lambda=0.71073 \AA)$ and intensity data were collected by the narrow frame method at low temperature (150 K). The structure was solved by direct method using SIR-2004 [35] and refined by full-matrix least-squares on F2 using the SHELXL-97 program [36] and Data were corrected for absorption effects by the Multi-Scan method [37]. Since the dichloromethane solvent molecule was grossly disordered and could not be modelled, its contribution was excluded using the subroutine SQUEEZE [38].

\section{Spectroscopy and photophysical measurements}

${ }^{1} \mathrm{H}$ NMR spectra were recorded on a Bruker AVANCE spectrometer (300 MHz). FTIR spectra were recorded in the region of $400-4000 \mathrm{~cm}^{-1}$ on a Nicolet Impact 410 spectrophotometer. UV-Vis spectra were measured with a Varian Cary 5000 spectrophotometer. Fluorescence spectra and quantum yield measurements were performed using a Varian Cary Eclipse luminescence spectrophotometer. Elemental analyses were carried out on a Flash EA 1112 Series Thermo Electron fitted with a Porapak column 2m PTFE + MX5 microbalance Mettler Toledo. The mass spectra were operated under electrospray ionization (ESI) positive.

\section{Results and discussion}

\section{Crystal structure description}

The molecular structure of studied [ $\mathrm{Mg}^{\mathrm{II}}$ (TPBP)(4,4'-bpy $)_{2}$ ] complex was investigated by single crystal X-ray crystallography. Single crystals were obtained by slow diffusion of hexane into dichloromethane solution of porphyrin at room temperature. Crystallographic data and structure refinement of $\left.\left[\mathrm{Mg}^{\mathrm{II}} \text { (TPBP)(4,4'-bpy }\right)_{2}\right]$ are given in Table 1 . The complex crystallizes in the monoclinic system, space group $\mathrm{P} 2 / \mathrm{c}$, with a $=17.5238(6) \AA, \mathrm{b}=$ 
11.6748(4) $\AA, \mathrm{c}=18.1690(5) \AA, \beta=114.212(1)^{\circ}, \mathrm{V}=2707.32 \AA^{3}, \mathrm{Z}=2$. Selected bond distances and angles are listed in Table S1.

A view of the repetitive unit is presented in Fig. 1, while two views of the onedimensional polymeric chain along $a$ axis, and the molecular packing arrangement are shown in Fig. 2 and 3, respectively. As reported in the literature, magnesium metalloporphyrins with monodentate axial ligands are generally exist as five-coordinated species [Mg(Porph)(X)] (X = neutral or anionic ligand) [39-41]. In few cases there exit also as six-coordinated derivatives $\left[\mathrm{Mg}(\mathrm{Porph})(\mathrm{L})_{2}\right]$ ( $\mathrm{L}=$ neutral axial monodentate ligand) i.e. [Mg(TPP)(py $\left.)_{2}\right]$ [42] and [Mg(TPP)(4-pic) $)_{2}$ complexes [43]. In the title magnesium(II) complex, the asymmetric unit presents one half $[\mathrm{Mg}(\mathrm{TPBP})(\mathrm{L})]\left(\mathrm{L}=4,4^{\prime}\right.$-bipyridine) complex. The coordination geometry around the $\mathrm{Mg}(\mathrm{II})$ cation is octahedral (Fig. 1), where the four donor $\mathrm{N}$ atoms of pyrrole rings of TPBP porphyrin occupy the equatorial positions. The apical positions of the $\mathrm{Mg}$ (II) are occupied by heterocyclic 4,4'-bpy trans- coordinated N3 and N4' atoms. Figure 2 and 3 show that the structure consist of $1 \mathrm{D}$ coordination polymer in which the bpy ligand serves as a bridge between adjacent magnesium(II) cations forming a linear chain.

The Mg—Nax distances range between $2.319 \AA(\mathrm{Mg}-\mathrm{N} 3)$ and $2.290 \AA$ (Mg-N4') indicating the strong coordination of 4,4'-bpy to metalloporphyrin which seems in agreement with $\mathrm{Mg}-\mathrm{Nax}$ bond length observed in [Mg(TPP)(py) $)_{2}$ (2.369 $\AA$ ) [42]. For [Mg(TPP)(4pic) $)_{2}$ [43], and $\left[\mathrm{Mg}(\mathrm{OEP})(\mathrm{py})_{2}\right]$ [44], the $\mathrm{Mg}-\mathrm{Nax}$ bonds are 2.386 and $2.389 \AA$, respectively, which seem very similar to those observed in our complex. However, the $\mathrm{Mg}$ Nax distance for $\left\{\left[\mathrm{Mg}(\mathrm{tn}-\mathrm{OEP})\left(4,4^{\prime} \text {-bpy }\right)_{2}\right]\right\}_{\mathrm{n}}$ polymer is found to be little shorter with 2.259 and $2.272 \AA$ values [22]. In comparison with other polymeric (bpy)-cobalt porphyrin complexes, the $\mathrm{Mg}-\mathrm{Nax}$ (bpy) distances is around $\sim 2.311-2.342 \AA$ [10]. The four $\mathrm{Mg}-\mathrm{Np}$ bonds consist of two sets of equal length 2.062 and $2.069 \AA$ as exists in the opposite pairs and fall on the range [2.063 - 2.100 $\AA$ ] of other reported $\mathrm{Mg}$ (II)-porphyrins (Table 2).

As observed in previously reported polymeric structures [21,22,45], the adjacent parallel porphyrin planes are perpendicular to the polymer chain direction (Fig. 3). The porphyrin core in this crystal structure is quasi-plane. The displacement of meso and betacarbons from the least-squares plane of $\mathrm{C}_{20} \mathrm{~N}_{4}$ pophyrinato core are $\pm 0,2497$ and $\pm 0,0983 \AA$ respectively. The displacement of the $\mathrm{Mg}(\mathrm{II})$ atom from the mean porphinato core is $0.072 \AA$. These displacements values are very close to those observed in analogous compounds with 4,4'-bipyridine [21]. The dihedral angles between $\mathrm{Np}-\mathrm{Mg}-\mathrm{N}$ (bpy) plan ( $\mathrm{Np}$ is the closest pyrrole nitrogen atom) and the first pyridyl moiety of 4,4'-bipyridine axial ligand is $1.67^{\circ}$, and the $4,4^{\prime}$-bpy molecule is twisted with dihedral angle $\Phi=58.45^{\circ}$ between the two pyridyl moieties (Fig. 4). In general, values of this dihedral angle in several 4,4'-bpy complexes range between $24^{\circ}$ and $46^{\circ}[10,21,46,47]$.

Crystal structure of studied complex consists of $1 \mathrm{D}$ polymeric chain extending along the [010] direction (Fig. 2 and 3) where the magnesium centres are bridged by 4,4'-bipy ligands, forming a linear Mg-bipy-Mg chain in which the $\mathrm{Mg} \cdot \cdots \mathrm{Mg}$ distance across the 4,4'bipy ligand is equal to $11.675 \AA$. This arrangement is similar to other described assemblies reported by Marijuan et all [45] and Mansour et all [21], in which the crystal structures are based on FeTPP and CoTPP units. They consist of 1D coordination polymers extending along the [010] and [100] directions respectively, where iron and cobalt porphyrins are axially 
bonded to two bipy ligands. The stability and cohesion of crystal packing are assured by intramolecular C37-H37L N2 non-conventional hydrogen bonds, and by weak C37H37L Cg2 interactions involving a carbon atom (C37) from coordinated 4,4'-bipyridine and the centroid of the pyrrole of the meso-porphyrin. The linear one-dimensional coordination chains are linked through weak C22-H22L Cg3 interactions (Fig. 5) involving a carbon atom (C22) of 4-formylphenylbenzoate and the centroid of 4,4'-bipyridine of neighbouring chains (CL centroid distance range $3.474 \AA$ ) (Table 3).

\section{IR and ${ }^{1} \mathrm{H}$ NMR spectroscopies}

In order to give more insights in the structure of porphyrin, metalloporphyrin and axial ligand, a detailed IR and ${ }^{1} \mathrm{H}$ NMR studies were made. FT-IR spectrum of the meso-porphyrin TPBP shows a band at $3329 \mathrm{~cm}^{-1}$, which is due to $-\mathrm{NH}_{2}$ stretching frequencies (Fig. S1a). The bands observed between 2964 and $2855 \mathrm{~cm}^{-1}$ are assigned to a $\mathrm{C}-\mathrm{H}$ vibration for the mesoporphyrin. The $\mathrm{C}=\mathrm{O}$ esters and $\delta(\mathrm{CCH})$ vibration modes occurred at ca. $1735 \mathrm{~cm}^{-1}$ and 987 $\mathrm{cm}^{-1}$ respectively. After insertion of magnesium ion into the porphyrin ring, the $\mathrm{N}-\mathrm{H}$ vibration frequency of free base porphyrin disappeared, indicating the formation of magnesium(II) porphyrin compound (Fig. S1b). According to the literature, IR spectrum of 4,4'-bipyridine undergoes a modification when coordinated with a metal cation [48-50]. The blue and red shift of observed bands are due to the formation of Mg-N(bpy) coordination bonds. In our present work (Fig. S1c), the $\mathrm{C}-\mathrm{C}$ and $\mathrm{C}-\mathrm{N}$ stretching vibration of 4,4'-bpy observed for the title complex, are relatively blue shifted from $1589 \mathrm{~cm}^{-1}$ to 1602 and $1609 \mathrm{~cm}^{-1}$ compared to those reported by Xiu-min et all. Moreover, the out-of-plane bending mode $\gamma(\mathrm{C}-\mathrm{H})$, for 4,4'bpy occurred at $807 \mathrm{~cm}^{-1}$ was blue-shifted to $846 \mathrm{~cm}^{-1}$. The in plane bending $\delta(\mathrm{C}-\mathrm{H})$ and $\delta(\mathrm{C}-\mathrm{N})$ modes for $4,4^{\prime}$-bpy at $1486 \mathrm{~cm}^{-1}$ were red shifted to $1463 \mathrm{~cm}^{-1}$.

For porphyrin $\mathrm{H}_{2} \mathrm{TPBP}$, the ${ }^{1} \mathrm{H}$ NMR spectroscopy allows us to identify eight $\beta$ pyrrole protons. The aromatic protons of the meso-phenyl rings resonating in the 8.91 to 7.59 ppm, which correspond to a classical case for all meso-porphyrins. The $\mathrm{NH}$ pyrrole protons are very shielded and appears at $-2.80 \mathrm{ppm}$ as low-intensity singlet (Fig. S2a). The insertion of magnesium metal ion into porphyrin ring is illustrated by the absence of inner imino proton $(\mathrm{NH})$ signal. A light shift of resonances towards low-field is also observed (at higher frequency) (Fig. S2b). The ${ }^{1} \mathrm{H}$ NMR spectrum of $\left[\mathrm{Mg}(\mathrm{TPBP})\left(4,4^{\prime}\right.\right.$-bpy) $\left.{ }_{2}\right]$ (Fig. S2c) indicates that the $\beta$-pyrrole protons resonate as a singlet at $8.98 \mathrm{ppm}$. The aromatic protons of the meso-phenyl rings resonating in the 8.46 to $7.67 \mathrm{ppm}$ range, which are slightly downfield (deshielded) compared to $\mathrm{Mg}(\mathrm{TPBP})$ and $\mathrm{H}_{2}$ TPBP compounds. The aromatic protons $(\mathrm{C}-\mathrm{H})$ of the axial 4,4'-bipyridine ligand are shifted to the weak field at $6.64 \mathrm{ppm}$.

\section{Photophysical properties}

UV-vis absorption spectroscopy. The UV-Vis spectrum of free base porphyrin $\mathrm{H}_{2}$ TBPP, starting materials [Mg(TBPP)] and synthesized complex, recorded in dichloromethane, are depicted in Fig. 6. The $\mathrm{H}_{2}$ TBPP shows a strong absorbance in the nearUV called the Soret or B band located at $419 \mathrm{~nm}$ (corresponding to strongly allowed transitions to the second excited state S0 $\rightarrow$ S2). In the visible region, four weak bands were 
observed, called the $Q$ bands, located at 527, 578, 582 and $655 \mathrm{~nm}$ (corresponding to the weakly allowed electronic transition to the first excited state S0 $\rightarrow \mathrm{S} 1$ ). The spectral features of Magnesium derivatives show that the $[\mathrm{Mg}(\mathrm{TBP})]$ exhibits an intense Soret band, together with two weak $Q$-bands between 500 and $700 \mathrm{~nm}$ and the complex [Mg ${ }^{\mathrm{II}}$ (TBPP)(4,4'-bpy) ${ }_{2}$, its Soret band appeared at $430 \mathrm{~nm}$ and its $Q$ bands at $571 \mathrm{mn}$ and $614 \mathrm{mn}$. Interestingly, the bands in the absorption spectrum of [Mg(TPBP)] are red shifted compared to $\mathrm{H}_{2} \mathrm{TBPP}$. Also, the $\left[\mathrm{Mg}^{\mathrm{II}}(\mathrm{TBPP})(4,4 \text { '-bpy })_{2}\right.$ ] associated spectrum is significantly red shifted up to $11 \mathrm{~nm}$ and 3 $\mathrm{nm}$ than these of the $\mathrm{H}_{2}$ TPBP as well as for [Mg(TBrPP)] respectively. Since both Soret and $Q$ bands arise from $\pi \rightarrow \pi *$ transitions, they can be explained by the Gouterman four orbital model (frontier HOMO and LUMO orbitals) [51,52]. The red shift of these bands indicates $\pi$ conjugation increasing and a HOMO-LUMO energy gap reduction [53-55] caused by the molecules symmetry increasing. The change in the symmetry from $\mathrm{D} 2 \mathrm{~h}$ in free base porphyrin to D4h in the metalloporphyrin leads only to two absorptions of $Q(0,0)$ and $Q(1,0)$ and a red shift. The UV/Vis. spectra data of all complex, with those of same species are collected in Table S2, indicate a bathochromic shift due to the insertion of the magnesium in the porphyrin core gives rise to the red shift of the visible absorption bands.

Steady-state emission spectroscopy. fluorescence spectra of free base porphyrin $\mathrm{H}_{2}$ TBPP, metalloporphyrin [Mg ${ }^{\mathrm{II}}$ (TPBP)], and synthesised complex have been recorded in dichloromethane $\left(\sim 10^{-6} \mathrm{~mol} \mathrm{~L}^{-1}\right)$ at room temperature and shown in Fig. 7. The fluorescence wavelength values of the $Q(0,0)$ and $Q(0,1)$ bands, the fluorescence quantum yields $\left(\Phi_{f}\right)$ of the magnesium porphyrin complex, the starting material $\mathrm{H}_{2}$ TBPP and those of analogues magnesium complexes are summarised in Table S3. For excitation in the Soret region of the spectrum $(420 \mathrm{~nm})$, the emission spectrum of the free porphyrin base is composed of two bands; a weak band around $719 \mathrm{~nm}$ assigned to $Q(0,1)$ (S2 [Q(0,1)] $\rightarrow \mathrm{S} 0$ ), and a stronger one at $651 \mathrm{~nm}$ assigned to the $Q(0,0)(\mathrm{S} 2[Q(0,0)] \rightarrow \mathrm{S} 0)$ electronic transition (Fig. S3a). The fluorescence spectra of starting material $\left[\mathrm{Mg}^{\mathrm{II}}(\mathrm{TPBP})\right]$ and final prepared complex are blue shifted compared, unlike the $\mathrm{H}_{2}$ TPBP free base. Excitation of the Soret bands results in two emission bands S2 $\rightarrow$ S0 which are nearly at the same energy; around $610 \mathrm{~nm}$ and $665 \mathrm{~nm}$ for $Q(0,0)$ and $Q(0.1)$, respectively. (Figs. S3b and S3c). As shown in Table S3 and Fig. 7, the main impact of the magnesium insertion resides in the huge blue shifts of $\sim 41 \mathrm{~nm}$ for the strongest emission band $Q(0,0)$, and $\sim 54 \mathrm{~nm}$ for the second band $Q(0,1)$. The fluorescence characteristics of our complex are similar to those already reported in the literature for [Mg $\left.^{\text {II }}(\mathrm{TPP})(\mathrm{HTMA})_{2}\right]$ [56] and [ $\left.\mathrm{Mg}^{\mathrm{II}}(\mathrm{TPP})(\mathrm{NCO})\right]^{-}$[40]. The fluorescence quantum yields of $\mathrm{H}_{2}$ TPBP, [Mg ${ }^{\text {II }}$ (TPBP)], and synthesised complex are in the range of [0.050 - 0.065] which are close to related magnesium metalloporphyrins.

\section{Conclusions}

In summary, the synthesis, spectral and photophysical properties of the new mesoporphyrin tetrakis[4-(benzoyloxy)phenyl]porphyrin $\mathrm{H}_{2} \mathrm{TPBP}$, the [Mg(TPBP)] starting material and the synthesised magnesium (II) porphyrin complex [Mg $\left.{ }^{\text {II }}(\mathrm{TPBP})(4,4 \text { '-bpy })_{2}\right]$ were performed. The UV-visible spectrum exhibits red-shifted Soret band compared to the $[\mathrm{Mg}(\mathrm{TPBP})]$ and the fluorescence data are practically the same as those of known magnesium porphyrin complexes. The single crystal molecular structure of this specie shows a $1 \mathrm{D}$ 
coordination polymer packing where the linear chains are arranged along the $b$ axis and are linked together by $\mathrm{C}-\mathrm{H} \cdots \mathrm{N}$ non-conventional hydrogen bonds and $\mathrm{C}-\mathrm{H} \cdots \pi$ interactions.

\section{Supplementary data}

Crystallographic data for the structure reported in this paper have been deposited within the Cambridge Crystallographic Data Centre as a supplementary publication No. CCDC 1581320. Copies of the data can be obtained, free of charge, on application to CCDC, 12 Union Road, Cambridge CB2 1EZ, UK, (fax: +44 1223336033 or e-mail: deposit@ccdc.cam.ac.uk).

\section{Acknowledgements}

The Authors thank The Tunisian Ministry of Higher Education and Scientific Research for the financial support. Nesrine Amiri is grateful to Professor Gilles Lemercier for the helpful discussions.

\section{Conflicts of interest}

The authors confirm that "there are no conflicts of interest to declare".

\section{References}

1. A. Nesrine, P. Maux, H. Srour, H. Nasri, G. Simonneaux, Tetrahedron. 70, 8836 (2014).

2. C. Maeda, T. Taniguchi, K. Ogawa, T. Ema, Angew. Chem. Int. Ed. 53, 1 (2014).

3. B. Gao, Y. Chen, Q. Lei, J. Incl. Phenom. Macrocycl. Chem. 74, 455 (2012).

4. C-W. Lee, H-P. Lu, C-M. Lan, Y-L. Huang, Y-R. Liang, W-N. Yen, Y-C. Liu, Y-S. Lin, E. W-G. Diau, C-Yu. Yeh, Chem. Eur. J. 15, 1403 (2009).

5. L. Lvova, P. Galloni, B. Floris, I. Lundström, R. Paolesse, C. D, Natale, Sensors. 13, 5841 (2013).

6. Y. Diskin-Posner, G. Kumar Patra, I. Goldberg, Chem. Commun. 1420 (2002).

7. E. Reddi, M. Ceccon, G. Valduga, G. Jori, J. C. Bommer, F. Elisei, L. Latterini, U. Mazzucato, Photochem. Photobiol. 75, 462 (2002).

8. N. Amiri, M. Hajji, F. Ben Taheur, S. Chevreux, T. Roisnele, G. Lemercier, H. Nasri, J. Solid State Chem. 258, 477 (2018).

9. J. Ramesh, S. Sujatha, C. Arunkumar, RSC Adv. (2016), DOI: 10.1039/C6RA09148B.

10. A. Mansour, M. Zaied, I. Ali, S. Soliman, M. Othmani, Polyhedron. 127, 496 (2017).

11. G. D. Bajju, G. Devi, S. Katoch, M. Bhagat, Deepmala, Ashu, S. Kundan, S. K. Anand, Bioinorg. Chem. Appl. (2013), http://dx.doi.org/10.1155/2013/903616.

12. C. Zhao, F. U. Rehman, Y. Yang, X. Li, D. Zhang, H. Jiang, M. Selke, X. Wang, C. Liu, Sci. Rep. (2015), DOI:10.1038/srep11518.

13. J. Schmitt, V. Heitz, A. Sour, F. Bolze, H. Ftouni, J. F. Nicoud, L. Flamigni, B. Ventura, Angew. Chem. Int. Ed. 53, 1 (2014).

14. K. Chang, Y. Tang, X. Fang, S. Yin, H. Xu, C. Wu, Biomacromolecules. 6, 2128 (2017).

15. B. F. Abrahams, B. F. Hoskins, R. Robson, J. Am. Chem. Soc. 113, 3606 (1991). 
16. E-Y. Choi, P. M. Barron, R. N. Novotny, C. Hu, Y-U. Kwon, W. Choe. CrystEngComm. 10, 824 (2008).

17. I. Goldberg, CrystEngComm. 4, 109 (2002).

18. L. Carlucci, G. Ciani, D. M. Proserpio, F. Porta, CrystEngComm. 7, 78 (2005).

19. B. F. Abrahams, B. F. Hoskins, D. M. Michail, R. Robson, Nature. 369, 727 (1994).

20. J. Bhuyan, S. Sarkar, Crys. Growth Des. 11, 5410 (2011).

21. A. Mansour, Y. Belghith, M. S. Belkhiria, A. Bujaczb, V. Guérineau, H. Nasri, J. Porphyr. Phthalocyanines. 17, 1 (2013).

22. S. A. Ikbal, S. Brahma, S. P. Rath, Inorg. Chem. 51, 9666 (2012).

23. P. N. Taylor, H. L. Anderson, J. Am. Chem. Soc. 121, 11538 (1999)

24. R. W. Seidel, R. Goddard, K. Focker, I. M. Oppel, CrystEngComm. 12, 387 (2010).

25. Q. Zha, C. Ding, X. Rui, Y. Xie, Cryst. Growth Des. 13, 4583 (2013).

26. G. Nandi, I. Goldberg, CrystEngComm. 16, 8327 (2014).

27. J. Bhuyan, S. Sarkar, Cryst. Growth Des. 11, 5410 (2011).

28. C. Xing, Q. Xu, H. Tang, L. Liu, S. Wang, J. Am. Chem. Soc. 131, 13117 (2009).

29. E. K. L. Yeow, P. J. Sintic, N. M. Cabral, J. N. H. Reek, M. J. Crossley, K. P. Ghiggino, Phys. Chem. Chem. Phys. 2, 428 (2000).

30. H. Imahori, N. V. Tkachenko, V. Vehmanen, K. Tamaki, H. Lemmetyinen, Y. Sakata, S. Fukuzumi, J. Phys. Chem. A. 105, 1750 (2001).

31. D. M. Carminati, D. Intrieri, S. L. Gac, T. Roisnel, B. Boitrel, L. Toma, L. Legnanic, E. Galloa, New J. Chem. 41, 5950 (2017).

32. M. F. Isaac, S. B. Kahl, J. Organomet. Chem. 680, 232 (2003).

33. J. S. Lindsey, H. C. Hsu, I. C. Schreiman, Tetrahedron Lett. 27, 4969 (1986).

34. K. M. Smith, Porphyrins and Metalloporphyrins, Elsevier: Amsterdam, The Netherlands, (1975).

35. M. C. Burla, R. Caliandro, M. Camalli, B. Carrozzini, G. L. Cascarano, L. De Caro, C. Giacovazzo, G. Polidori, R. Spagna, J. Appl. Cryst. 38, 381 (2005).

36. G. M. Sheldrick, Acta Cryst. A64, 112 (2008).

37. P. J. Becker, P. Coppens, Acta Cryst. A30, 129 (1974).

38. A. L. Spek, J. Appl. Crystallogr. 36, 7 (2003).

39. K. Ezzayani, Z. Denden, E. Saint-Aman, N. Najmudin, F. Loiseau, H. Nasri, Eur. J. Inorg. Chem. 31, 5348 (2014).

40. K. Ezzayani, A. B. Khelifa, E. Saint-Aman, F. Loiseau, H. Nasri, Polyhedron. 117, 817 (2016).

41. L. Jiang, R. A. Zaenglein, J. T. Engle, C. M. Mittal, C. S. Hartley, C. J. Ziegler, H. Wang, Chem. Commun. 48, 6927 (2012).

42. G. Wu, A. Wong, S. Wang, Can. J. Chem. 81, 275 (2003).

43. V. McKee, C. C. Ong, G. A. Rodley, Inorg. Chem. 23, 4242 (1984).

44. R. Bonnett, M. B. Hursthouse, M. K. M. Abdul, B. J. Mateen, J. Chem. Soc., Perkin Trans. 2, 2072 (1977).

45. A. F. Marijuan, E. Amayuelas, G. Barandika, B. Bazán, M. K. Urtiaga, M. I. Arriortua, Molecules. 20, 6683 (2015).

46. A. D. Shukla, P. C. Dave, E. Suresh, A. Das, P. Dastidar, Dalton Trans. 4459 (2000). 
47. A. Fidalgo-Marijuan, G. Barandika, B. Bazan, M. K. Urtiaga, L. Lezama, M. I. Arriortua, Inorg. Chem. 52, 8074 (2013).

48. S. Xiu-min, W. Hai-yan, HUI Ge, L. Yan-bing, Y. Jing-xiu, C. Lei, X. Wei-qing, Z. Bing, Chem. Res. Chin. Univ. 26, 1011 (2010).

49. D. M. Czakis-Sulikowska, J. Radwanska-Doczckalska, G. Sojka, Monatsh. Chem. 115, 961 (1984).

50. P. Zhu, L. Kan, X. Han, J. Feng, J. Jia, X. Zhang, Dyes Pigm. 113, 55 (2015).

51. A. M. Shaffer, M. Gouterman, Theor. Chim. Acta. 25, 62 (1972).

52. M. Gouterman, J. Chem. Phys. 30, 1139 (1959).

53. R. Tiwari, M. Nath, New J. Chem. 39, 5500 (2015).

54. R. A. Binstead, M. J. Crossley, N. S. Hush. Inorg. Chem. 30, 1259 (1991).

55. J. A. Shelnutt, V. Ortiz, J. Phys. Chem. 89, 4733 (1985).

56. K. Ezzayani, A. B. Khelifa, E. Saint-Aman, F. Loiseau, H. Nasri, J. Mol. Struct. 1137, 412 (2017). 


\section{Table Caption}

Table 1 Crystal and refinement data of complex (I).

Table 2 Selected bond lengths $[\AA]$ in several hexacoordinate magnesium porphyrin complexes ${ }^{\mathbf{a}}$.

Table 3 Inter-and intramolecular interactions for (I). 
Table 1

Complex (I)

\begin{tabular}{ll}
\hline Chemical formula & $\mathrm{C}_{82} \mathrm{H}_{55} \mathrm{Mg} \mathrm{N}_{6} \mathrm{O}_{8}$ \\
Formula weight & 1273.61 \\
Crystal system & monoclinic \\
Space group & $\mathrm{P} 2 / \mathrm{c}$ \\
$a[\AA]$ & $17.5238(6)$ \\
$b[\AA]$ & $11.6748(4)$ \\
$c[\AA]$ & $18.1690(5)$ \\
$\alpha[\AA]$ & 90 \\
$\beta[\AA]$ & $114.212(1)$ \\
$\theta[\AA]$ & 90 \\
$V\left[\AA \AA^{3}\right]$ & $3390.16(19)$ \\
$Z$ & 2 \\
$D$ calcd. [g/cm $\left.{ }^{3}\right]$ & 1.248 \\
$\mu$ [mm ${ }^{-1}$ ] & 0.090 \\
Max./min. transmission & $0.982 / 0.991$ \\
$F(000)$ & 1324 \\
Crystal size [mm] & $0.28 / 0.17 / 0.1$ \\
$T$ (K) & 150 \\
Unique data & 7778 \\
Unique obsd data & 5967 \\
Final $R$ indices & $R_{1}=0.0765, w R_{2}=0.2652$ \\
\hline & \\
&
\end{tabular}


Table 2

\begin{tabular}{llll}
\hline Compound & $\mathbf{M}^{-} \mathbf{N}_{\mathbf{p}} \mathbf{b}^{\mathbf{b}}$ & $\mathbf{M}-\mathbf{N}_{\mathbf{a x}}{ }^{\mathbf{c}}$ & Ref \\
\hline$\left[\mathrm{Mg}(\mathrm{TPP})(\mathrm{py})_{2}\right]$ & 2.063 & 2.369 & {$[42]$} \\
{$\left[\mathrm{Mg}(\mathrm{TPP})(4-\mathrm{pic})_{2}\right]$} & 2.071 & 2.386 & {$[43]$} \\
{$\left[\mathrm{Mg}(\mathrm{TPP})(\mathrm{pip})_{2}\right]$} & 2.071 & 2.419 & {$[43]$} \\
{$\left[\mathrm{Mg}(\mathrm{OEP})(\mathrm{py})_{2}\right]$} & 2.068 & 2.389 & {$[44]$} \\
{$\left[\mathrm{Mg}(\text { tn-OEP)(4,4'-bpy })_{2}\right]$} & $2.087-2.100$ & $2.259-2.272$ & {$[22]$} \\
{$\left[\mathrm{Mg}(\mathrm{TPBP})\left(4,4^{\prime}-\text {-bpy }\right)_{2}\right](\mathbf{1})$} & 2.065 & $2.319-2.290$ & this work
\end{tabular}

${ }^{a}$ Distances in $[\AA]$

b. Average equatorial metal-nitrogen pyrrole distance;

c: Distance between the metal and the nitrogen of the N-donor ligand.

Table 3

\begin{tabular}{|c|c|c|c|}
\hline D-H ...A ${ }^{a}$ & Symmetry of A & D-H...A [Å] & D...A [ $\left.{ }^{\circ}\right]$ \\
\hline C37-H37...N2 & $1-x, y, 3 / 2-z$ & 122 & $3.189(3)$ \\
\hline C37-H37...Cg2 & $1-x, y, 3 / 2-z$ & 147 & $3.665(3)$ \\
\hline C22-H22...Cg3 & $2-x, 1-y, 2-z$ & 167 & $3.474(2)$ \\
\hline
\end{tabular}

${ }^{\mathrm{a}} \mathrm{D}=$ donor atom and $\mathrm{A}=$ acceptor atom.

Cg2 is the centroid of the N2-C6-C7-C8-C9 five membered ring,

Cg3 is the centroid of the N3-C37-C38-C39-C38D-C37d six membered ring, 


\section{Figure caption}

Fig. 1 The building repetitive unit of [Mg $\left.{ }^{\mathrm{II}}(\mathrm{TPBP})\left(4,4^{\prime} \text {-bpy }\right)_{2}\right]$ (I).

Fig. 2 View of the 1D polymeric chain along $a$ axis.

Fig. 3 Projection along the $c$ axis of the atomic arrangement (for clarity, the $\mathrm{H}$ atoms are omitted).

Fig. 4 Diagram of porphyrin core of (I) showing the mean plane displacements of the $\mathrm{Mg}(\mathrm{II})$ ion and the core atoms $(\AA)$ and the dihedral angle $\left(^{\circ}\right)$ between the two pyridyl moieties of the 4,4'-bpy molecule.

Fig. 5 Schematic representation showing the weak $\mathrm{C}-\mathrm{HL} \mathrm{N}$ and $\mathrm{C}-\mathrm{HL} \mathrm{Cg}$ intermolecular interactions in (I). Cg are the centroids of pyrrole and 4,4'-bipyridine ligand.

Fig. $6 \mathrm{UV}$-vis absorption spectra of $\mathrm{H}_{2} \mathrm{TPBP}$, [Mg $\left.{ }^{\mathrm{II}}(\mathrm{TPBP})\right]$, and $\left[\mathrm{Mg}^{\mathrm{II}}(\mathrm{TPBP})\left(4,4^{\prime}-\mathrm{bpy}\right)_{2}\right]$, in $\mathrm{CH}_{2} \mathrm{Cl}_{2}$ solution at concentrations of $1.3410^{-6}, 1.610^{-6}$, and $1.210^{-6} \mathrm{~mol}$. $\mathrm{L}^{-1}$ respectively.

Fig. 7 Emission spectra of the starting material $\mathrm{H}_{2}$ TPBP, $[\mathrm{Mg}(\mathrm{TPBP})]$, and $\left[\mathrm{Mg}^{\mathrm{II}}(\mathrm{TPBP})\left(4,4^{\prime}-\right.\right.$ bpy) $)_{2}$ ] complex. 
$c{ }^{b}-a$

$\mathrm{C}$
$\mathrm{O}$
$\mathrm{O}$

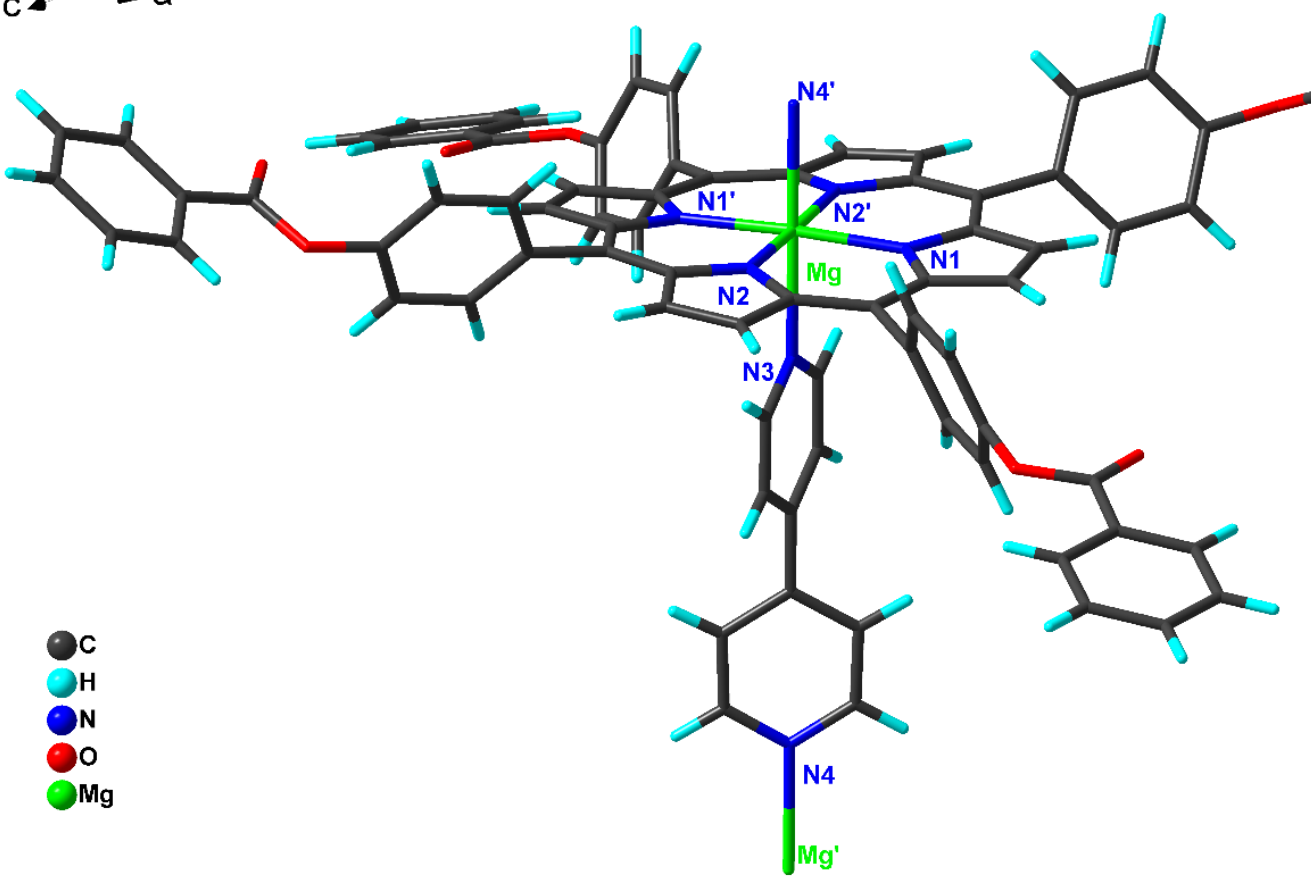

Fig. 1

Fig. 2

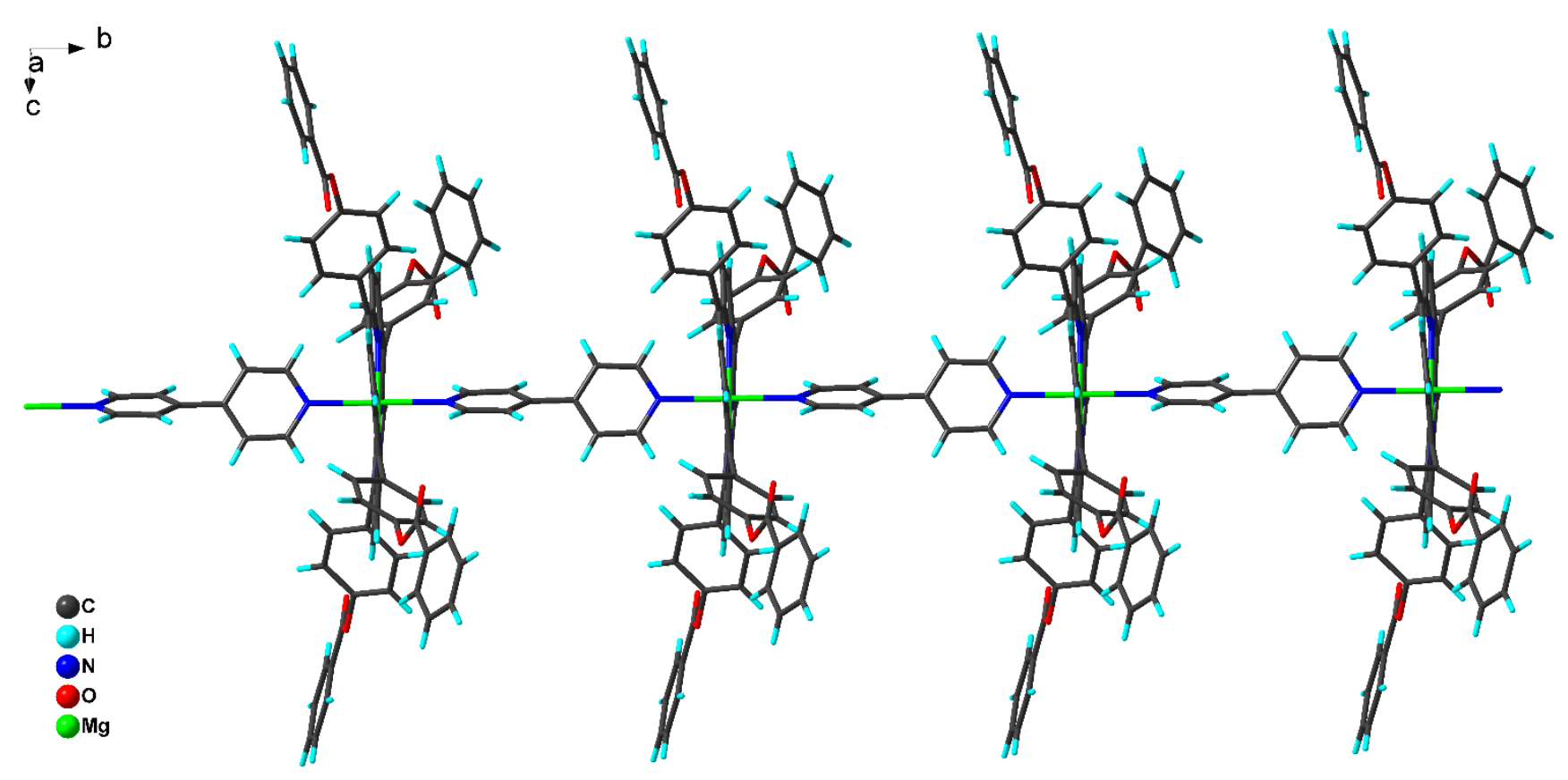




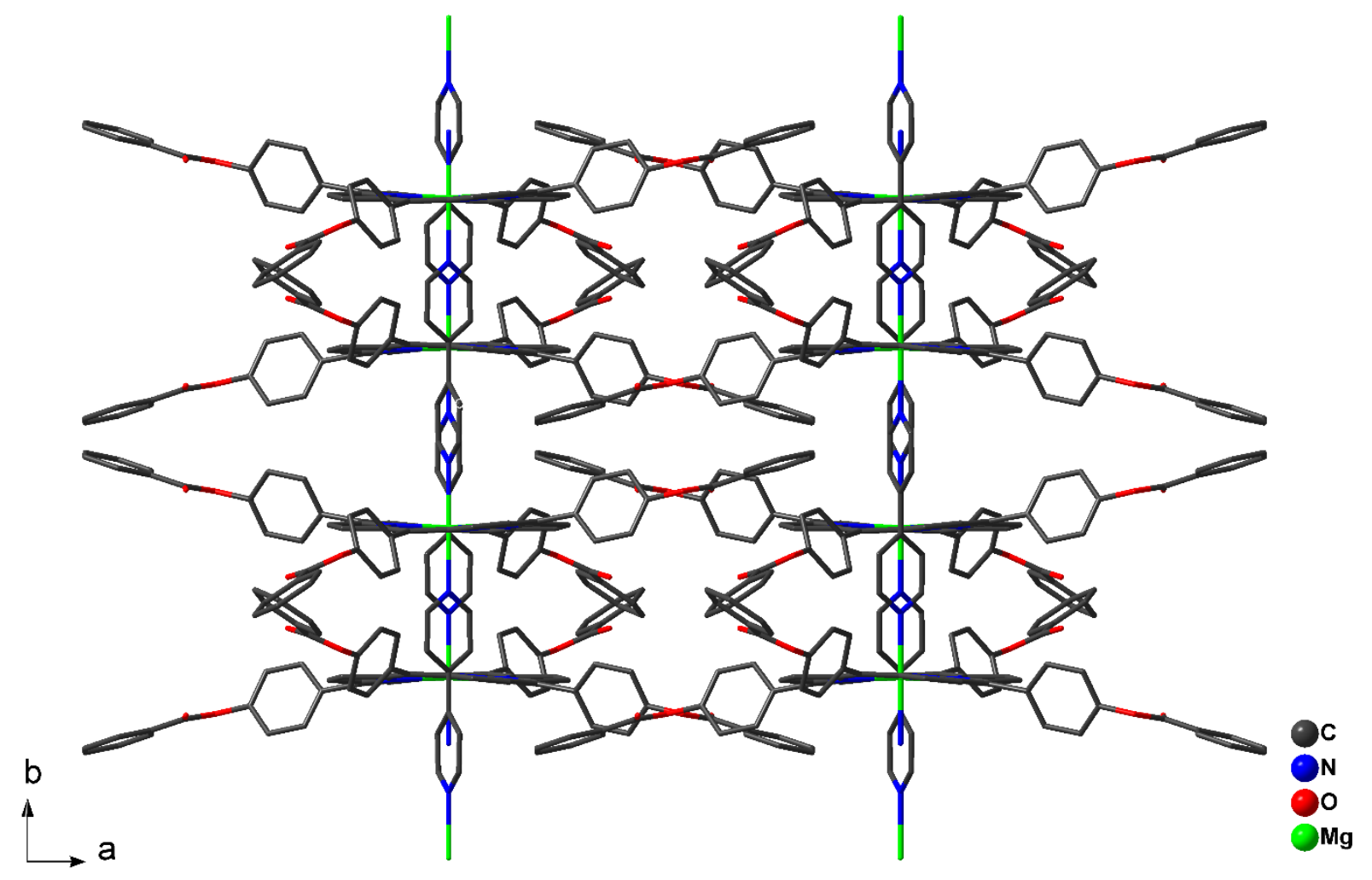

Fig. 3 


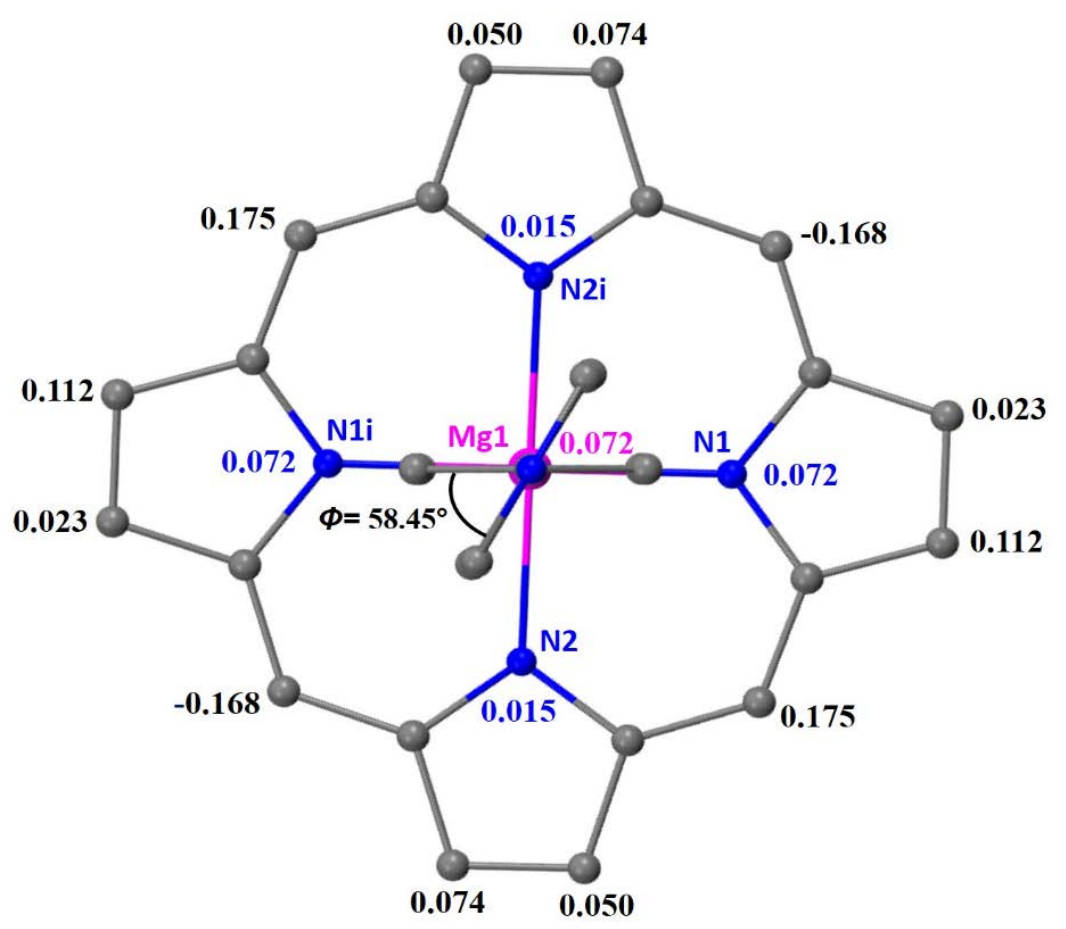

Fig. 4 


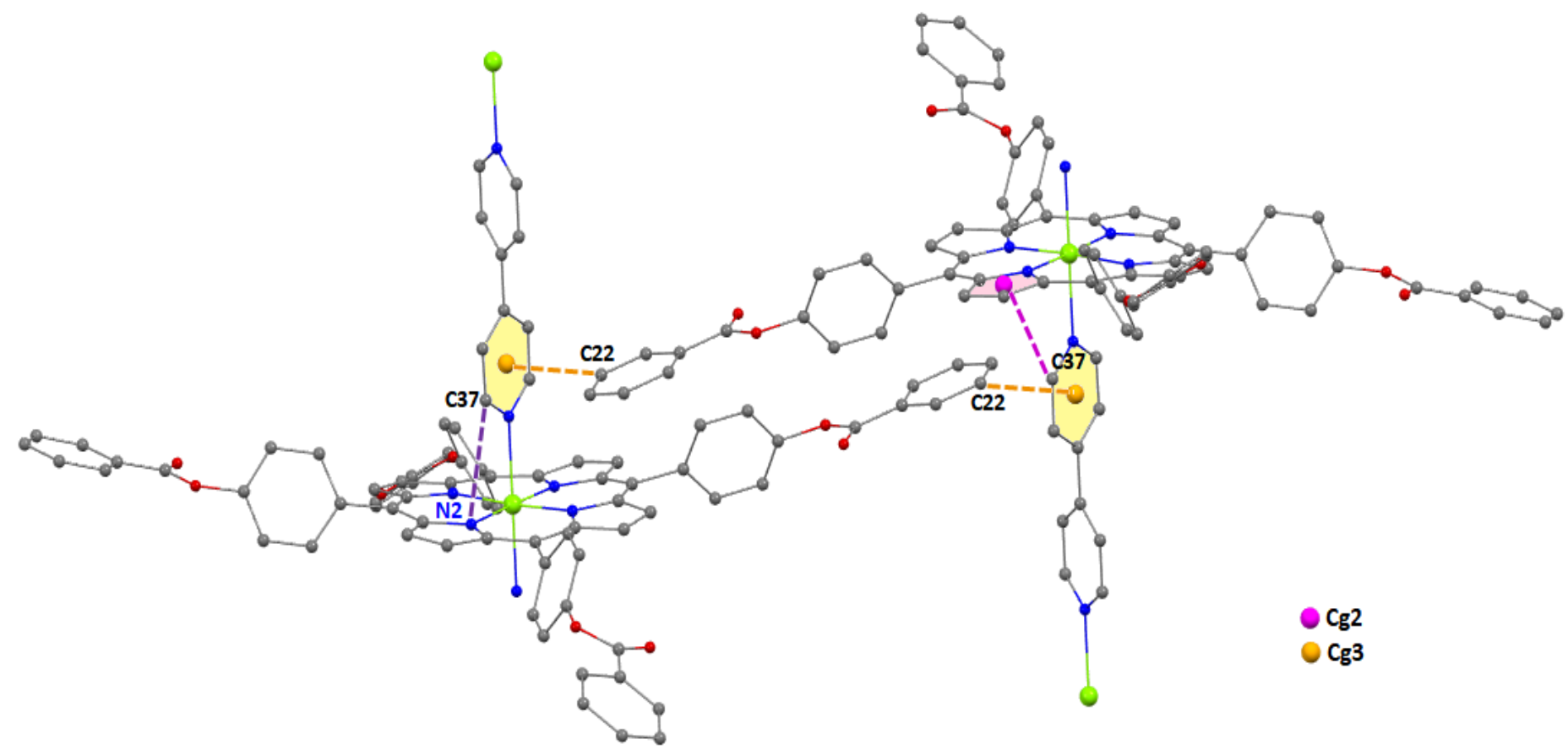

Fig. 5

Fig. 6

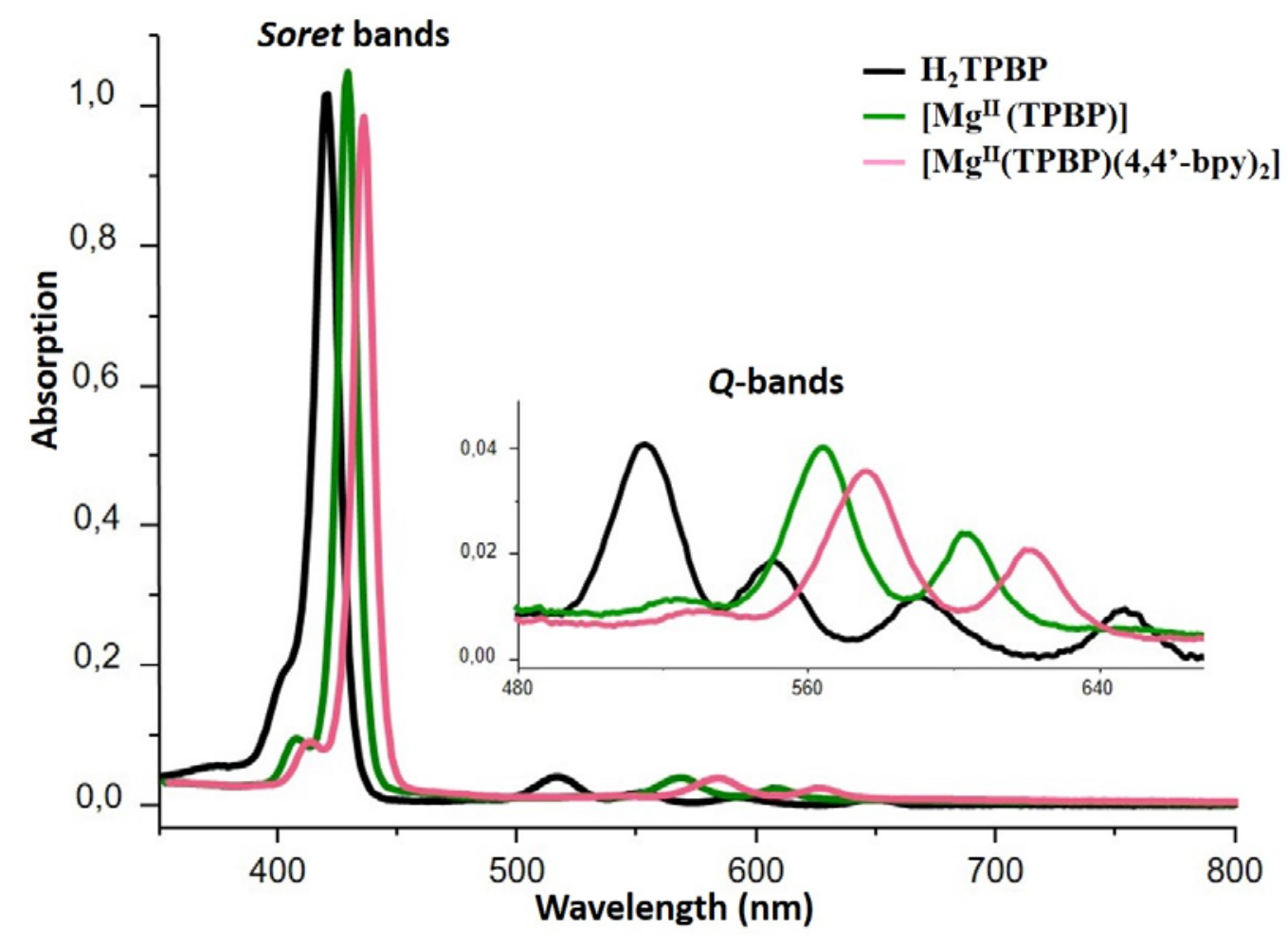




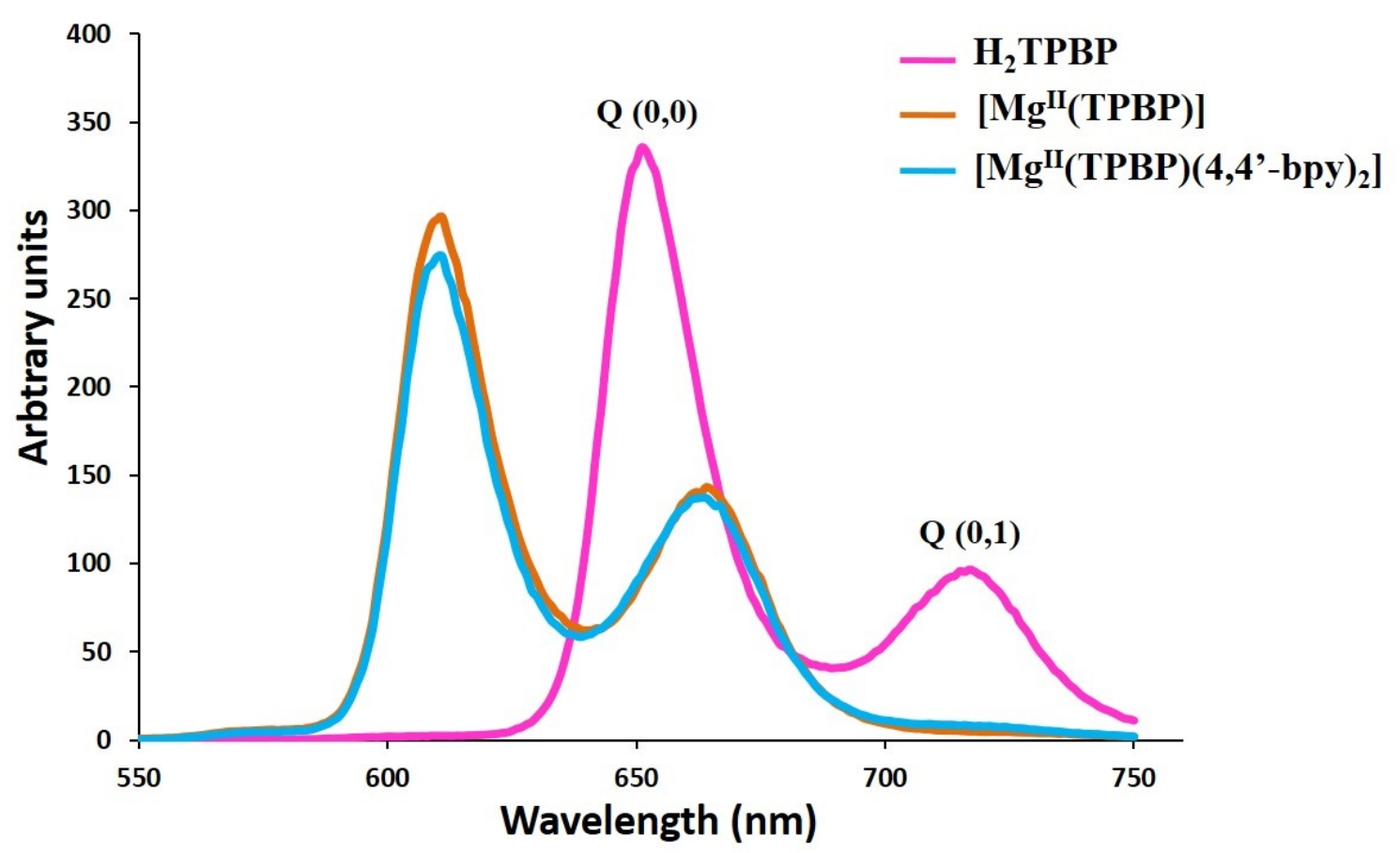

Fig. 7 


\title{
Electronic Supplementary Information (ESI)
}

Synthesis, Molecular structure, Photophysical Properties and Spectroscopic Characterization of New 1D-Magnesium (II) Porphyrin-Based Coordination Polymer

\author{
N. Amiri ${ }^{\text {a }}$ M. Hajji ${ }^{b} * \bullet$ T. Roisnel $^{c} \cdot$ G. Simonneaux $^{c} \cdot$ H. Nasri ${ }^{\text {a }}$ \\ a Laboratory of Physical Chemistry of Materials, University of Monastir, Avenue of the Environment, 5019 Monastir, \\ Tunisia. \\ ${ }^{\mathrm{b}}$ Research Unit: Electrochemistry, Materials and Environment, University of Kairouan, 3100 Kairouan, Tunisia. \\ ${ }^{c}$ Institute of Chemical Sciences of Rennes UMR 6226, University of Rennes 1, Beaulieu Campus, 35042 Rennes, France. \\ * Corresponding author: Email: melekhajji1989@gmail.com T: (+216) 55367281 ORCID: 0000-0002-6145-2858.
}

\section{Table of contents}

No. Contents

Pg No.

1 Scheme S1 Main chemical preparation steps.

2 Table S1 Selected bond lengths $[\AA]$ and angles $\left[{ }^{\circ}\right]$.

3 Table S2 UV/Vis data of several free base meso-porphyrins, our complex and a selection of magnesium meso-metalloporphyrins in dichloromethane.

4 Table S3 Emission data of $\mathrm{H}_{2}$ TPBP and a selection of magnesium meso-tetraphenylporphyrins.

$5 \quad$ Fig. S1 IR spectra of: $\mathrm{H}_{2}$ TPBP (a), [Mg(TPBP)] (b) and [Mg ${ }^{\mathrm{II}}$ (TPBP)(4,4'-bpy) ${ }_{2}$ (I) (c).

$6 \quad$ Fig. S2 ${ }^{1} \mathrm{HNMR}$ spectra of: $\mathrm{H}_{2} \mathrm{TPBP}$ (a), [Mg(TPBP)] (b) and [Mg ${ }^{\mathrm{II}}(\mathrm{TPBP})\left(4,4{ }^{\prime}-\text {-bpy) }\right)_{2}$ (I) (c). The green arrow indicates the shift of protons towards low-field.

7 Fig. S3 Absorption, excitation and emission spectra in dichloromethane. (a): $\mathrm{H}_{2} \mathrm{TPBP}$, (b): [Mg(TPBP)], (c): [Mg $\left.{ }^{\mathrm{II}}(\mathrm{TPBP})\left(4,4^{\prime}-\text {-bpy }\right)_{2}\right]$ (I). Concentration $\sim 10^{-6} \mathrm{M}$.

8 References 


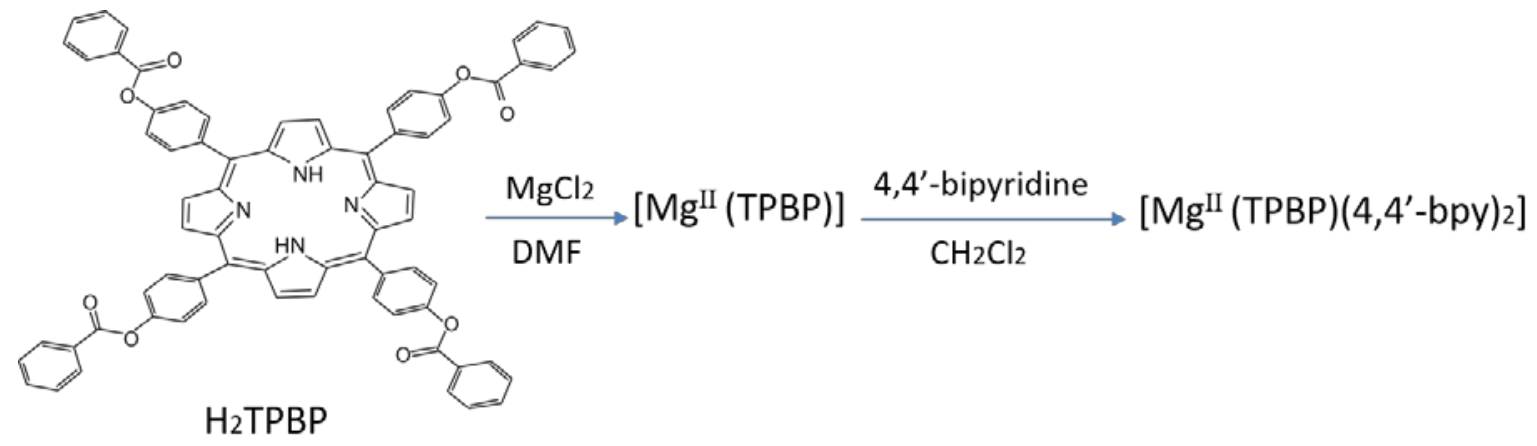

Scheme S1 Main chemical preparation steps. 
Table S1 Selected bond lengths $[\AA]$ and angles $\left[^{\circ}\right]$.

\begin{tabular}{llll}
\hline \multicolumn{4}{c}{ Cobalt coordination polyhedron } \\
\hline Mg1-N1 & $2.062(2)$ & N1-Mg1-N2 & $90.81(9)$ \\
Mg1-N2 & $2.069(2)$ & N1-Mg1-N3 & $88.29(6)$ \\
Mg1-N3 & $2.319(3)$ & N1-Mg1-N4 & $91.71(6)$ \\
Mg1-N4 & $2.290(3)$ & \\
\hline \multicolumn{4}{c}{4,4 'bipyridine ligand } \\
\hline N3-C37 & $1.339(3)$ & C42-N4-Mg1 & $121.57(15)$ \\
N4-N42 & $1.329(3)$ & C37-N3-Mg1 & $121.75(15)$ \\
\hline
\end{tabular}

Table S2 UV/Vis data of several free base meso-porphyrins, our complex and a selection of magnesium mesometalloporphyrins in dichloromethane.

\begin{tabular}{|c|c|c|c|c|c|c|}
\hline Compound & $\begin{array}{c}\text { Soret band } \\
\lambda[\mathrm{nm}](\log \varepsilon)\end{array}$ & & $\begin{array}{r}\mathbf{Q} \\
\lambda[\mathbf{n n}\end{array}$ & $\begin{array}{l}\text { ands } \\
(\log \varepsilon)\end{array}$ & & [ref] \\
\hline $\mathrm{H}_{2} \mathrm{TPP}$ & $416(6.10)$ & $513(5.70)$ & $550(4.36)$ & $590(4.24)$ & $646(4.19)$ & [1] \\
\hline $\mathrm{H}_{2} \mathrm{TTP}$ & $420(5.95)$ & $515(5.82)$ & $555(4.28)$ & $595(4.17)$ & $650(4.10)$ & [1] \\
\hline $\mathrm{H}_{2}^{2} \mathrm{TPBP}$ & $419(5.92)$ & $515(4.47)$ & $551(4.14)$ & $590(3.95)$ & $646(3.84)$ & this work \\
\hline$\left[\mathrm{Mg}^{\mathrm{II}}(\mathrm{TPP})\right]$ & $424(5.87)$ & $563(4.52)$ & $603(4.39)$ & & & [2] \\
\hline$\left[\mathrm{Mg}^{\mathrm{II}}(\mathrm{TPP})\right]$ & 424 (8.09) & $563(6.54)$ & $602(6.30)$ & & & [2] \\
\hline$\left[\mathrm{Mg}^{\mathrm{II}}(\mathrm{TPBP})\right]$ & $427(5.88)$ & $565(4.45)$ & $605(4.17)$ & & & this work \\
\hline$\left[\mathrm{Mg}^{\mathrm{II}}(\mathrm{TPBP})\left(4,4^{\prime} \text {-bpy }\right)_{2}\right](\mathbf{I})$ & $430(6.03)$ & $571(5.07)$ & $614(5.00)$ & & & this work \\
\hline$\left[\mathrm{Mg}^{\mathrm{II}}(\mathrm{TPP})(\mathrm{HTMA})_{2}\right]$ & $434(6.22)$ & 575 (4.97) & $617(4.98)$ & & & [3] \\
\hline
\end{tabular}

Table S3 Emission data of $\mathrm{H}_{2} \mathrm{TPBP}$ and a selection of magnesium meso-tetraphenylporphyrins.

\begin{tabular}{|c|c|c|c|c|c|}
\hline Compound & $Q(0,0)[\mathrm{nm}]$ & $Q(0,1)[\mathrm{nm}]$ & $\boldsymbol{\Phi}_{f}$ & Solvent & [Ref] \\
\hline $\mathrm{H}_{2} \mathrm{TPP}$ & 654 & 712 & 0.110 & $\mathrm{CH}_{2} \mathrm{Cl}_{2}$ & [4] \\
\hline $\mathrm{H}_{2} \mathrm{TPP}$ & 656 & 717 & 0.09 & $\mathrm{CH}_{2} \mathrm{Cl}_{2}$ & [5] \\
\hline $\mathrm{H}_{2} \mathrm{TPBP}$ & 653 & 715 & 0.038 & $\mathrm{CH}_{2} \mathrm{Cl}_{2}$ & [6] \\
\hline $\mathrm{H}_{2} \mathrm{TPBP}$ & 651 & 719 & 0.054 & $\mathrm{CH}_{2} \mathrm{Cl}_{2}$ & this work \\
\hline$\left[\mathrm{Mg}^{\mathrm{II}}(\mathrm{TPP})\right]$ & 608 & 665 & 0.150 & $\mathrm{CH}_{2} \mathrm{Cl}$ & [4] \\
\hline$\left[\mathrm{Mg}^{\mathrm{II}}(\mathrm{TPP})\right]$ & 608 & 661 & 0.150 & $\mathrm{CH}_{2} \mathrm{Cl}_{2}$ & [2] \\
\hline$\left[\mathrm{Mg}^{\mathrm{II}}(\mathrm{TPBP})\right]$ & 610 & 665 & 0.050 & $\mathrm{CH}_{2} \mathrm{Cl}_{2}$ & this work \\
\hline$\left[\mathrm{Mg}^{\mathrm{II}}\right.$ (TPBP) $\left.\left(4,4^{\prime} \text {-bpy }\right)_{2}\right](\mathbf{I})$ & 611 & 665 & 0.065 & $\mathrm{CH}_{2} \mathrm{Cl}_{2}$ & this work \\
\hline$\left[\mathrm{Mg}^{\mathrm{II}}(\mathrm{TPP})(\mathrm{HTMA})_{2}\right]$ & 620 & 665 & 0.14 & $\mathrm{CH}_{2} \mathrm{Cl}_{2}$ & [3] \\
\hline$\left[\mathrm{Mg}^{\mathrm{II}}(\mathrm{TPP})(\mathrm{NCO})\right]^{-}$ & 609 & 659 & 0.11 & $\mathrm{CH}_{2} \mathrm{Cl}_{2}$ & [2] \\
\hline
\end{tabular}




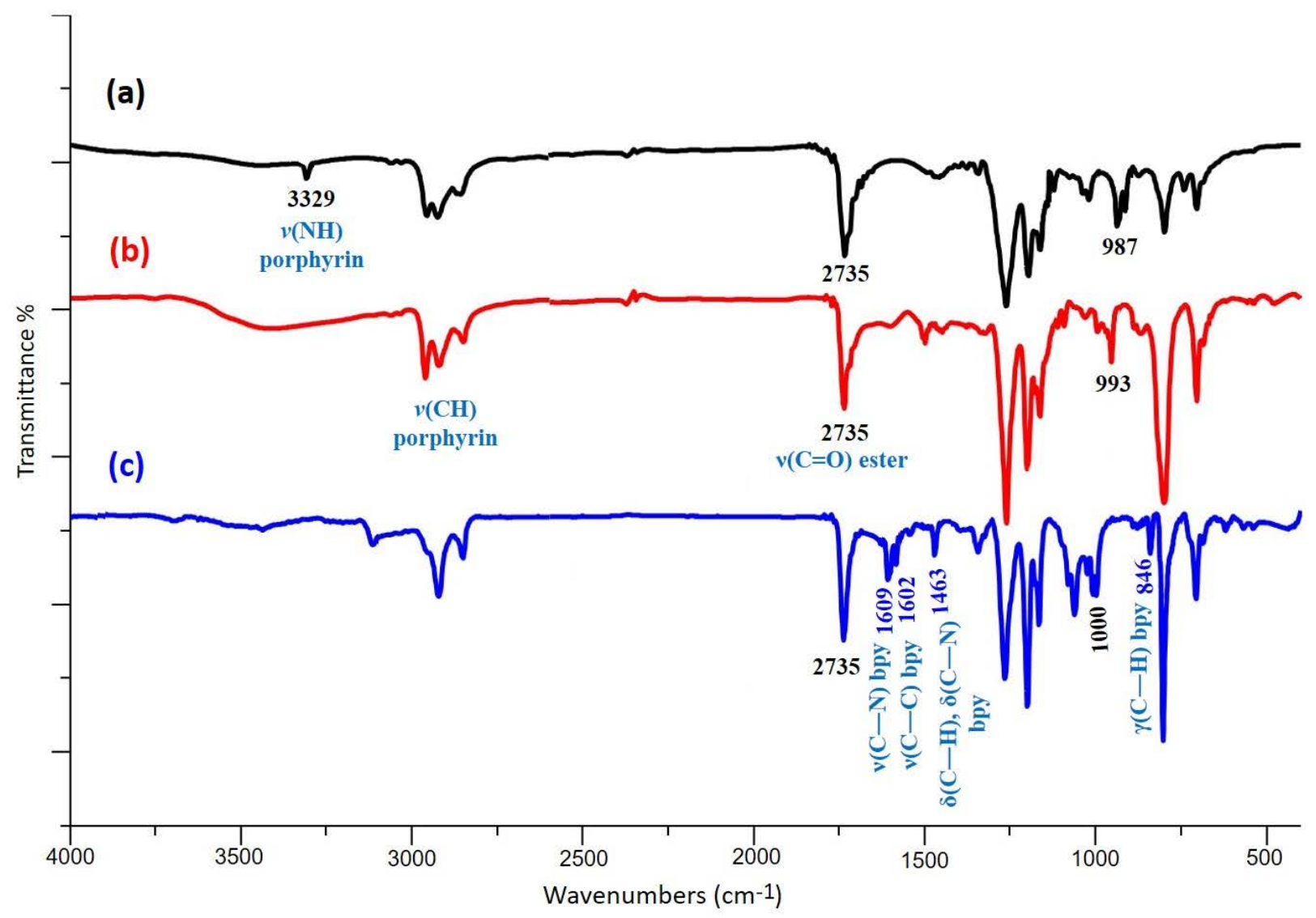

Fig. S1 IR spectrum spectra of: $\mathrm{H}_{2} \mathrm{TPBP}(\mathrm{a})$, [Mg(TPBP)] (b) and [Mg ${ }^{\mathrm{II}}(\mathrm{TPBP})\left(4,4^{\prime}-\text {-bpy) }\right)_{2}$ (I) (c). 


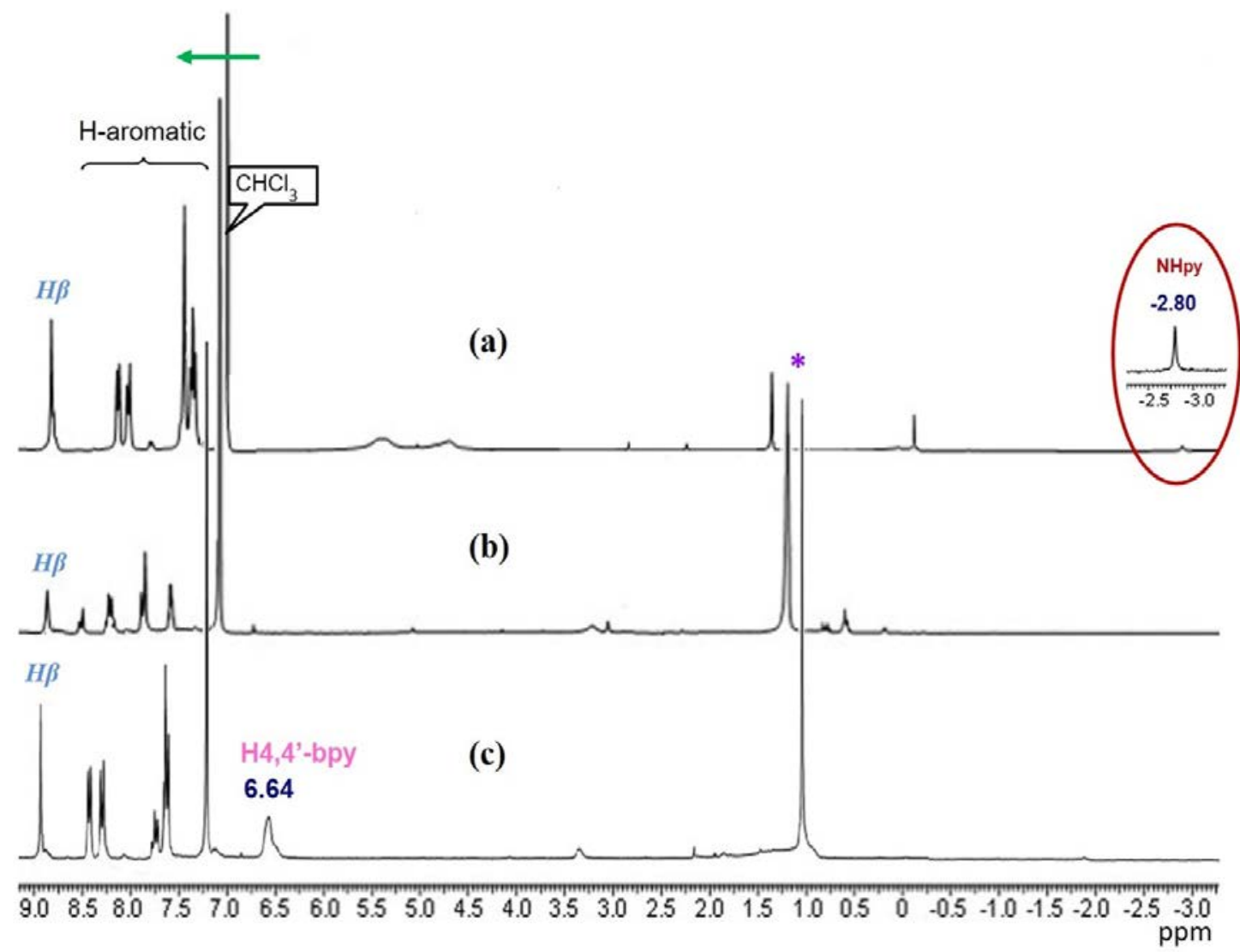

Fig. S2 ${ }^{1}$ HNMR spectra of: $\mathrm{H}_{2}$ TPBP (a), [Mg(TPBP)] (b) and [Mg ${ }^{\text {II }}$ (TPBP)(4,4'-bpy) $\left.{ }_{2}\right]$ (I) (c). The green arrow indicates the shift of protons towards low-field. 

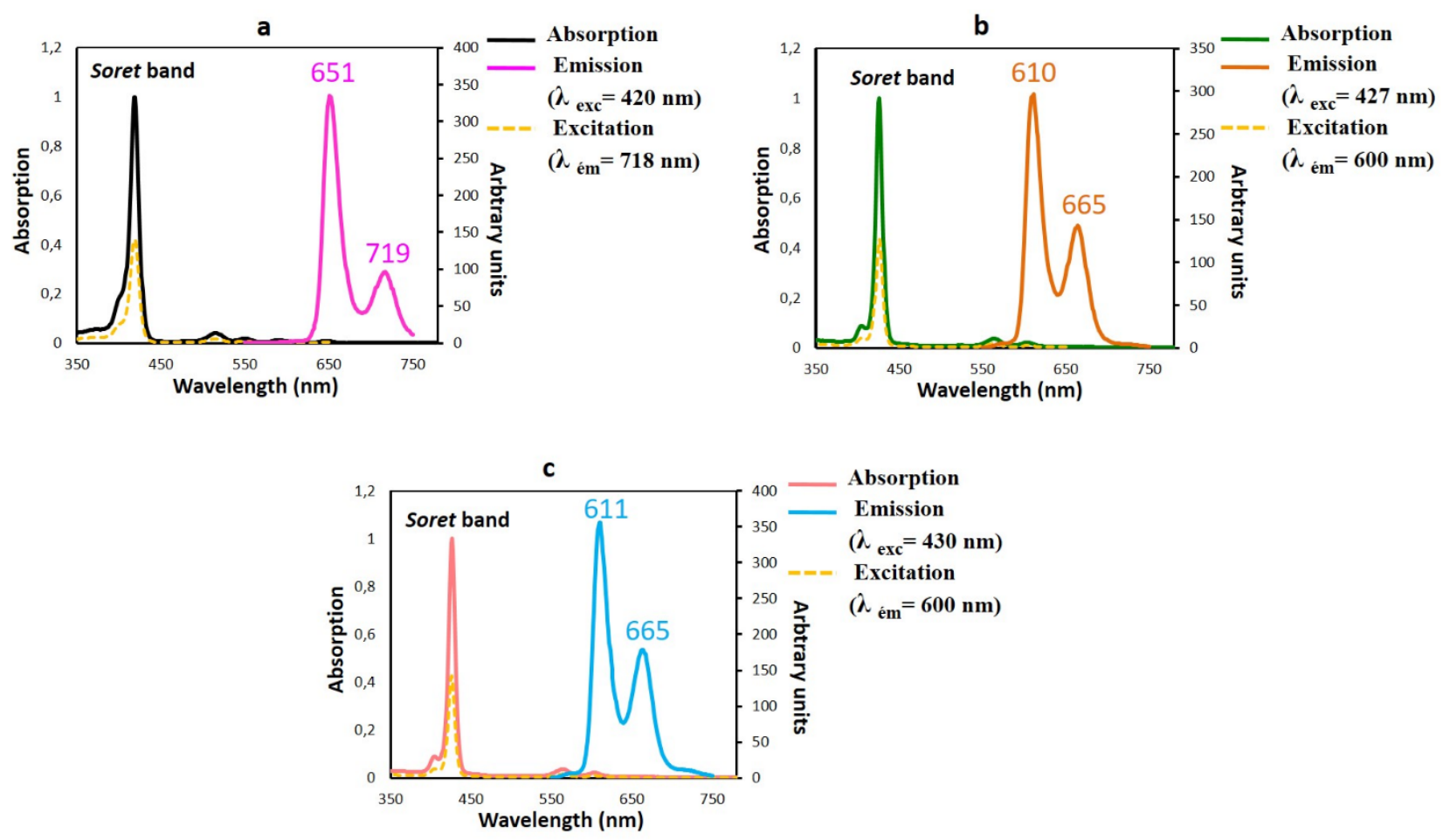

Fig. S3 Absorption, excitation and emission spectra in dichloromethane. (a): $\mathrm{H}_{2} \mathrm{TPBP}$, (b): [Mg(TPBP)], (c): $\left[\mathrm{Mg}^{\mathrm{II}}(\mathrm{TPBP})\left(4,4^{\prime}-\text {-bpy }\right)_{2}\right](\mathbf{I})$. Concentration $\sim 10^{-6} \mathrm{M}$. 


\section{References}

1. Z. Denden, K. Ezzayani, E. Saint-Aman, F. Loiseau, S. Najmudin, C. Bonifácio, J.-C. Daran, H. Nasri, Eur. J. Inorg. Chem. 15, 2596 (2015).

2. K. Ezzayani, A. B. Khelifa, E. Saint-Aman, F. Loiseau, H. Nasri, Polyhedron. 117, 817 (2016).

3. K. Ezzayani, A. B. Khelifa, E. Saint-Aman, F. Loiseau, H. Nasri, J. Mol. Struct. (2017). DOI : 10.1016/j.molstruc.2017.02.054.

4. J. Zhang, P. Zhang, Z. Zhang, X. Wei, J. Phys. Chem. A. 113, 5367 (2009).

5. E. J. Shin and D. Kim, J. Photochem. Photobiol. A: Chem. 152, 25 (2002).

6. S. Nasri, I. Zahou, I. Turowska-Tyrk, T. Roisnel, F. Loiseau, E. Saint-Amant, H. Nasri, Eur. J. Inorg. Chem. 31, 5004 (2016). 